bô câu hỏi xây dựng từ hành vi mua TPCN của người tiêu dùng tại TPHCM xây dựng được, với cõ̃ mẫu lớn hơn nhiêu so với các đề tài trước đây là 506 người, dân số mang tính đại diện với đầy đủ các nhóm tuổi, nhóm ngành nghề, tuy nhiên, việc lựa chọn mẫu còn chưa thực sự chặt chẽ, cần thực hiện chọn mẫu cụ thể và rổ ràng hơn. So với nghiên cứu của tác giả Nguyễn Thị Thu Hà, 2015 (287 người chưa từng sử dụng TPCN ở Đà Nẵng) và Hoàng Thị Phương Thảo, 2016 (300 người đã từng mua và/hoặc sử dụng TPCN tại TPHCM), cõ mẫu của nghiên cứu này lớn hơn và tập trung hơn vào người tiêu dùng tại TPHCM nên đã cung cấp được thông tin cập nhật trong dữ liệu nghiên cứu thị trường cho doanh nghiêp - đây là nguồn tham khảo chi tiết và cập nhật hơn khi các doanh nghiệp muốn tìm hiểu và phát triển sản phẩm TPCN ${ }^{3,4}$.

Tuy nhiên, nghiên cứu chỉ mới dừng lại ở bước xây dựng bộ câu hỏi điều tra tình hình sử dụng TPCN của NTD tại TPHCM (nhân khẩu học, mục đích sử dụng TPCN, nguồn tìm kiếm thông tin của NTD, kiến thức, thái độ, niềm tin, cảm nhận về giá của NTD về TPCN...). Vì vậy, cần có các nghiên cứu phân tích sâu hơn về ảnh hưởng của các yếu tố này đến mức độ chấp nhận và sử dụng TPCN. Hơn nữa, các nghiên cứu thị trường chỉ đúng trong khoảng thời gian tiến hành nghiên cứu, doanh nghiệp cần tiến hành thường xuyên nếu muốn hiểu rõ̃ thị hiếu NTD từ đó đề ra chiến lược kinh doanh phù hợp nhất trong từng khoảng thời gian nhất định.

\section{KẾT LUÂN}

Trong bối cảnh TPCN ngày càng phát triển thì cơ hội đâuu tư cho các doanh nghiệp ngày càng rộng mở, đồng thời cũng là thách thức trong việc quản lý của cơ quan chức năng. Bộ câu hỏi hoàn thiện đã hỗ trợ cung cấp thông tin đầy đủ, khách quan cho các doanh nghiệp trong quá trình nghiên cứu thị trường, đồng thời giúp nhà quản lý có cái nhìn toàn diên trong công tác quản lý về việc sử dụng TPCN của NTD. Cả 4 thành phần: (1) Thái độ, (2) Kiến thức, (3) Niềm tin, (4) Giá cả đều ảnh hưởng rất lớn đến sự chấp nhận TPCN của NTD, không thể xem nặng hay xem nhẹ bất kỳ thành phần nào, đây cũng là một trong những cơ sở để đưa ra các giải pháp đối với các doanh nghiệp trong việc thay đổi hành vi sử dụng TPCN của người tiêu dùng.

\section{TÀI LIẸU THAM KHẢO}

1. Trân Đáng (2014), Số liêu thị trường TPCN 2000 - 2013, Hiệp hội Thực Phẩm Chức Năng.

2. Kotler P. et al. (2012), Marketing management 14th Edition, Pearson Prentice Hall, Upper Saddle River, NJ, pp. 98-118.

3. Nguyễn Thị Thu Hà (2015), Nghiên cứu các yếu tổ ảnh hưởng đến ý định mua thực phẩm chức năng của ngưới tiêu dùng tại Đà Nẵng, luận văn thạc sĩ, trường đại học Đà năng, thành phố Đà Nẵng.

4. Hoàng Thị Phương Tháo (2016), Mức độ chấp nhận thực phẩm chức năng của người tiêu dùng, tạp chí đại học mở thành phố Hồ Chí Minh.

5. K. A. Bollen (1989), Structural equations with latent variables, Wiley, New York.

6. Tổng điêuu tra dân số và nhà ở trung ương (2019), Tổng điều tra dân số và nhà ở năm 2019, Tổng Cục Thống kê, http://tongdieutradanso.vn/ tphcm-cong-bo-ket-qua-so-bo-tong- dieu-tra-danso-va-nha-o-nam-2019.html, ngày truy cập 23/04-2020.

7. Hair, J.F., Black, W.C., Babin, B.J., \& Anderson, R.E. (2010). Multivariate Data Analysis. Seventh Edition. Prentice Hall, Upper Saddle River, New Jersey.

8. Menrad, K. (2003) Market and Marketing of Functional Food in Europe. Journal of Food Engineering, 56, 181-188.

\title{
NGHIÊN CỨU TÁC DỤNG CHỐNG VIÊM THỰC NGHIỆM CỦA VIÊN NANG HỖ TRỢ ĐIỀU TRI ECZEMA
}

\section{TÓM TẮT}

Mục tiêu: Đánh giá được tác dụng chống viêm của viên nang hỗ trợ điêuu trị eczema trên chuột cống trắng. Đối tượng và phương pháp: Viên nang hô

\author{
${ }^{1}$ Trường Đai hoc Dước Hà Nôi \\ Chịu trách nhiệm chính: Nguyễn Mạnh Tuyển \\ Email: tuyennm@hup.edu.vn \\ Ngày nhận bài: 4.3.2021 \\ Ngày phản biên khoa hoc: 22.4.2021 \\ Ngày duyệt bài: 4.5.2021
}

\section{Phạm Thái Hà Văn ${ }^{1}$, Nguyễn Mạnh Tuyển ${ }^{1}$}

trợ điều trị eczema được bào chế từ cao chiết ethanol của bài thuốc hỗ trợ điều trị eczema. Đánh giá tác dụng chống viêm cấp theo phương pháp gây tràn dịch màng bụng chuột bằng carrageenin; tác dụng chống viêm mạn theo phương pháp gây u hạt thực nghiệm. Kết quả: Viên nang hố trợ điều tri eczema có tác dụng chống viêm cấp ở chuột cống trẳng trên mô hình gẩy viêm phúc mac ở liều tương đương lâm sàng $0,6 \mathrm{~g} / \mathrm{kgTT}$ và $1,8 \mathrm{~g} / \mathrm{kg} T$. Trên mô hình gây u hạt thực nghiệm, viên nang hố trợ điều trị eczema có tác dụng chống viêm mạn ở liểu tương đương lâm sàng $0,6 \mathrm{~g} / \mathrm{kg} T \mathrm{~T}$ và $1,8 \mathrm{~g} / \mathrm{kgTT}$, tác dụng này tương đương 
với prednisolon liêu $5 \mathrm{mg} / \mathrm{kg}(\mathrm{p}>0,05)$. Kết luận: Viên nang hỗ trợ điều trị eczema thể hiện cả tác dụng chống viêm cấp và chống viêm mạn ở các mô hình nghiên cứu trên chuột cống trắng.

Tư khóa: viên nang, hỗ trợ điêu trị eczema, chống viêm

\section{SUMMARY \\ STUDY ON EXPERIMENTAL ANTI- \\ INFLAMMATORY EFFECTS OF ANTI ECZEMA CAPSULES}

Objectives: To evaluate the anti-inflammatory effect of anti eczema capsule in rats. Subjects and methods: anti eczema capsule was evaluated the acute anti-inflammatory effect by the method of causing peritoneal effusion by carrageenin and chronic anti-inflammatory effects by the method of causing granulomatous experiments. Results: anti eczema capsule have anti acute inflammatory effect and on the model of peritonitis and anti chronic inflammatory effect on the granulomatous model in rats with the doses of $0.6 \mathrm{~g} / \mathrm{kgBW}$ (equivalent to the clinical dose) and $1,8 \mathrm{~g} / \mathrm{kgBW}$ (equivalent to three times of the clinical dose) which equivalent to prednisolone dose of $5 \mathrm{mg} / \mathrm{kg}$ ( $p>0.05)$. Conclusion: anti eczema capsule show both acute and chronic antiinflammatory effects in research models in rats.

Keywords: capsule, anti eczema, antiinflammatory.

\section{I. ĐĂT VẤN ĐỀ}

Bài thuốc hỗ trợ điêuu trị eczema gôm 6 vị kim ngân đằng (Caulis cum folium Lonicerae), hòe hoa (Flos Styphnolobii japonici imaturi), đơn lá đỏ (Folium Excoecariae), núc nác (Cortex Oroxyli), thương nhĩ tử (Fructus Xanthii strumarii), hoàng bá (Cortex Phellodendri) được thiết kế trên cơ sở lý luận y dược học cổ truyền và các nghiên cứu về hoá học, tác dụng dược lý hiên đaî, được sử dụng trên lâm sàng ở dạng thuốc thang cho hiệu quả điều trị tích cực. Trong các nghiên cứu trước đây, chúng tôi đã tiến hành bào chế cao đặc bài thuốc và đánh giá tính an toàn, tác dụng chống viêm, chống dị ứng của cao đặc cho kết quả khả quan [1], [2]. Từ các kết quả thu được, chúng tôi đã tiến hành bào chế viên nang cứng từ cao đặc bài thuốc và tiến hành đánh giá độc tính cấp, độc tính bán trường diễn. Kết quả cho thây viên nang cứng hỗ trợ điều trị eczema an toàn ở liều thử nghiệm. Bài báo này trình bày các kết quả nghiên cứu về tác dụng chống chống viêm cấp và mạn của viên nang hỗ trợ điều trị eczema trên chuột cống trắng.

\section{II. ĐỐI TƯợNG VÀ PHƯƠNG PHÁP NGHIÊN CỨU 2.1. Đối tượng nghiên cứu}

- Viên nang hỗ trợ điêuu trị eczema được bào chế từ cao đặc chiết ethanol của bài thuốc gôm 6 vị kim ngân đằng (Caulis cum folium
Lonicerae), hòe hoa (Flos Styphnolobii japonici imaturi), đơn lá đỏ (Folium Excoecariae), núc nác (Cortex Oroxyli), thương nhĩ tử (Fructus Xanthii strumarii), hoàng bá (Cortex Phellodendri) đạt Dược điển Việt Nam.

- Hoá chất, dung môi nghiên cứu: NaCMC, methylprednisolon, compound 48/80, $\mathrm{NaCl}$, nước cất... đạt tiêu chuẩn Dược điển Việt Nam.

- Động vật thí nghiệm: Chuột cống trắng, giống cái khỏe mạnh, trọng lượng 180-220g, do Học viện Quân Y cung cấp. Súc vật được nuôi trong điêu kiện phòng thí nghiệm với đây đủ thức ăn và nước uống tại Bộ môn Dược lực Trường Đại học Dược Hà Nội.

\subsection{Phướng pháp nghiên cứu}

- Tác dụng chống viếm cấp:

*Nguyên lý: Sử dụng phương pháp gây tràn dịch màng bụng chuột bằng carrageenin theo Winter và cộng sự: Tác nhân gây tràn dịch màng bụng chuột là dịch treo carrageenan, formaldehyd pha trong nước muối sinh lý.

*Tiến hành: Chia ngẫu nhiên động vật thí nghiệm thành 4 lô, mỗi lô 10 con:

- Lô 1 (chứng): uống dung dịch NaCMC 5\%, $1 \mathrm{~mL} / 100 \mathrm{~g}$ thể trọng (TT).

- Lô 2 (chứng dương): uống prednisolon pha trong NaCMC $5 \%$ liêu 5 mg/kg, 1mL/100g TT.

- Lô 3 (viên nang liều tương đương lâm sàng): uống dịch cốm thuốc trong ruột viên nang hỗ trợ điều trị eczema pha trong dung dịch NaCMC 5\% ở mức liêu tương đương lâm sàng $(0,6 \mathrm{~g} / \mathrm{Kg} \mathrm{TT}), 1 \mathrm{~mL} / 100 \mathrm{~g}$ TT.

- Lô 4 (viên nang liều cao): uống dịch cốm thuốc trong ruột viên nang hố trợ điều trị eczema pha trong dung dịch Na CMC 5\% ở mức liêu gấp 3 lân liêuu tương đương lâm sàng $(1,8 \mathrm{~g} / \mathrm{Kg} \mathrm{TT}), 1 \mathrm{~mL} / 100 \mathrm{~g}$ TT.

- Chuột được cho uống mẫu thử hàng ngày trong 5 ngày liên tục. Vào ngày thứ 5 , sau khi cho uống dung môi, thuốc đối chiếu và chế phẩm nghiên cứu 1 giờ, tiến hành gây viêm màng bụng bằng hỗn dịch: carrageenin $0,05 \mathrm{~g}+$ formaldehyd $1,4 \mathrm{ml}$ pha trong nước muối sinh lý vừa đủ $100 \mathrm{~mL}$, liều $2 \mathrm{ml} / 100 \mathrm{~g}$ thể trọng chuột, tiêm vào khoang màng bụng. Sau 24 giờ gây viêm, giết chuột, mổ chuột hút dịch rỉ viêm trong ổ bụng. Đo thể tích và đếm số lượng bạch câu/ml dịch rỉ viêm, định lượng protein trong dịch rỉ viêm.

- Tác dụng chống viêm mạn:

*Nguyên lý: sử dụng phương pháp ức chế u hạt thực nghiệm.

*Tiến hành: Chia ngẫn nhiên động vật thí nghiệm thành các lô và cho uống thuốc thử với 
thể tích, liều lượng như trên. Sau khi cho uống dung môi, thuốc đối chiếu và chế phẩm thử lần đầu 30 phút, chuột được gây mê bằng diethyl ether. Cạo sạch lổng vùng lưng phía trên, sát trùng bằng betadin $10 \%$, dùng mũi kéo bấm một lỗ nhỏ ở da, luồn hai mũi kéo qua lỗ thủng, tách kỹ để da không dính vào cơ rồi cấy viên bông có trọng lượng chính xác khoảng $20 \mathrm{mg}$ đã tiệt trùng được tẩm dung dịch carrageenan $1 \%$ vào nơi đã bóc tách da. Chuột tiếp tục được cho uống dung môi, thuốc đối chiếu và chế phẩm thử hàng ngày trong 7 ngày liên tục. Đến ngày kết thúc thực nghiệm, sau khi cho uống thuốc thử lần cuối cùng 5 giờ, giết chuột bằng xông hơi diethyl ether, bóc tách u hạt dưới da lưng. Cân, xác định ngay khối lượng u hạt tươi. Sau đó sây khô u hạt đến khối lượng không đổi ở $60^{\circ} \mathrm{C}$ rồi cân, xác định khối lượng u hạt khô.

\section{Thông số đánh giá:}

+ Khối lượng u hạt tươi/khô của từng chuột (sau khi đã trừ khối lượng trước khi cấy).

+ Tỉ lệ \% độ giảm khối lượng u hạt của lô thử so với lô chứng biểu thị theo công thức sau:

$$
\mathrm{X} \%=\left[\left(\mathrm{M}_{\mathrm{c}}-\mathrm{M}_{\mathrm{t}}\right) / \mathrm{M}_{\mathrm{c}}\right] \times 100
$$

Trong đó:

X\% : Tỷ lệ \% giảm trọng lượng u hạt của lô thử so với lô chứng.

Mc: Khối lượng u hạt trung bình của lô chứng.

$\mathrm{M}_{\mathrm{t}}$ : Khối lượng u hạt trung bình của lô thử.

- Xử lý số liệu: Số liệu thực nghiệm được tổng hợp và xử lý thống kê bằng phần mềm Microsoft Excel. So sánh sự khác biệt giá trị trung bình các chỉ số quan sát giữa các lô thử bằng test $\mathrm{T}$.

\section{KẾT QUẢ NGHIÊN CỨU VÀ BÀN LUẬN}

\subsection{Tác dụng chống viêm cấp}

Bảng 3.1. Trọng lượng các lổ chuột trước và sau thực nghiệm

\begin{tabular}{|c|c|c|c|c|}
\hline \multirow{2}{*}{ Lô thử $(n=10)$} & \multirow{2}{*}{$\begin{array}{l}\text { Liều thử } \\
\text { (/KgTT) }\end{array}$} & \multicolumn{2}{|c|}{ Trọng lượng $(g, X \pm \mathbf{S D})$} & \multirow{2}{*}{$\mathbf{P}$} \\
\hline & & Trước & Sau & \\
\hline Lô 1: Dung môi (NaCMC 5\%) (1) & $0,1 \mathrm{ml}$ & $190,9 \pm 15,3$ & $185,4 \pm 16,3$ & $>0,05$ \\
\hline Lô 2: Prednisolon (2) & $5 \mathrm{mg}$ & $195,3 \pm 12,9$ & $193,1 \pm 13,3$ & $>0,05$ \\
\hline $\begin{array}{l}\text { Lô 3: Viên nang hô trợ điều trị eczema, } \\
\text { liêu tương đương lâm sàng (3) }\end{array}$ & $0,6 \mathrm{~g}$ &, 3 & $\pm 16,9$ & $>0,05$ \\
\hline $\begin{array}{c}\text { Lô 4: Viên nang hô trợ điều trị eczema, } \\
\text { liêu cao (4) }\end{array}$ & $1,8 \mathrm{~g}$ & $196,6 \pm 14,2$ & $193,3 \pm 16,3$ & $>0,05$ \\
\hline $\mathrm{P}$ & & $>$ & 5 & \\
\hline
\end{tabular}

Nhận xét: 24 giờ sau tiêm dung dịch carrageenin - formaldehyd vào khoang màng bụng chuột, trọng lượng trung bình của các nhóm chuột thực nghiệm có xu hướng giảm so với trước khi tiêm, nhất là ở lồ chuột đối chứng cho uống nước cất. Tuy nhiên khi so sánh trọng lượng giữa các lô chuột uống thuốc, sự khác biệt là không có ý nghĩa thống kê ( $p>0,05)$.

Bảng 3.2. Ánh hưởing của viên nang hố trợ điều trị eczema tới các chỉ tiêu xét nghiệm dich ri viêm $(X \pm S D)$

\begin{tabular}{|c|c|c|c|c|}
\hline \multirow[b]{2}{*}{ Lô thử $(n=10)$} & \multirow[b]{2}{*}{$\begin{array}{l}\text { Liều thủ } \\
\text { (/KgTT) }\end{array}$} & \multicolumn{3}{|c|}{ Chỉ tiêu } \\
\hline & & $\begin{array}{l}\text { Lượng dịch rì } \\
\text { viêm }(\mathrm{ml})\end{array}$ & $\begin{array}{l}\text { Hàm lượng } \\
\text { protein }(\mathbf{m g} / \mathrm{dl})\end{array}$ & $\begin{array}{l}\text { Số lượng bạch } \\
\text { cầu }(K / u \bar{l})\end{array}$ \\
\hline Lô 1: Dung môi (NaCMC 5\%) (1) & $0,1 \mathrm{ml}$ & $4,85 \pm 0,67$ & $5,69 \pm 0,64$ & $12,98 \pm 3,61$ \\
\hline Lô 2: Prednisolon (2) & $5 \mathrm{mg}$ & $2,16 \pm 0,56$ & $3,01 \pm 0,53$ & $6,82 \pm 0,82$ \\
\hline $\begin{array}{c}\text { Lô 3: Viên nang hố trợ điều trị eczema, } \\
\text { liêu tương đương lâm sàng (3) }\end{array}$ & $0,6 \mathrm{~g}$ & $2,43 \pm 0,48$ & $3,32 \pm 0,41$ & $7,21 \pm 0,91$ \\
\hline $\begin{array}{c}\text { Lô 4: Viên nang hô trợ điều trị eczema, } \\
\text { liều cao (4) }\end{array}$ & $1,8 \mathrm{~g}$ & 32 & , 35 & ,80 \\
\hline$P$ & & $\begin{array}{c}\mathrm{p}_{1-2} ; \mathrm{p}_{1-3} ; \mathrm{p}_{1-4} \\
<0,05 ; \\
\mathrm{p}_{2-3} ; \mathrm{p}_{2-4} ; \mathrm{p}_{3-4} \\
>0,05\end{array}$ & $\begin{array}{c}\mathrm{p}_{1-2} ; \mathrm{p}_{1-3} ; \mathrm{p}_{1-4} \\
<0,05 ; \\
\mathrm{p}_{2-3} ; \mathrm{p}_{2-4 ;} \mathrm{p}_{3-4} \\
>0,05\end{array}$ & $\begin{array}{c}\mathrm{p}_{1-2} ; \mathrm{p}_{1-3} ; \mathrm{p}_{1-4} \\
<0,05 ; \\
\mathrm{p}_{2-3} ; \mathrm{p}_{2-4} ; \mathrm{p}_{3-4} \\
>0,05\end{array}$ \\
\hline
\end{tabular}

Nhân xét: Kết quả cho thấy, viên nang hỗ trợ điều trị eczema ở liều tương đương lâm sàng $0,6 \mathrm{~g} / \mathrm{kg} T \mathrm{~T}$ và liều gấp 3 lần liều tương đương lâm sàng $(1,8 \mathrm{~g} / \mathrm{kgTT})$ đều làm giảm thể tích dịch rỉ viêm, giảm hàm lượng protein trong dịch rỉ viêm và làm giảm số lượng bach câu trong dịch rỉ viêm so với lô chứng $(p<0,05)$, kết quả này tương đương với chuột cống trẳng uống dùng prednisolon $5 \mathrm{mg} / \mathrm{kg}(\mathrm{p}>0,05)$. Sự khác biệt giữa 2 mức liều thử không có ý nghĩa thống kê $(p>0,05)$.

\subsection{Tác dụng chống viêm mạn}


Bảng 3.3. Trọng lượng khôi u hạt thực nghiệm tươi ở các lô chuột thử nghiệm

\begin{tabular}{|c|c|c|c|c|}
\hline Lô thử $(n=10)$ & $\begin{array}{l}\text { Liêu thứ } \\
\text { (/KgTT) }\end{array}$ & $\begin{array}{l}\text { Trọnglượng } \\
\text { (mg, } X \pm \text { SD) }\end{array}$ & $\begin{array}{l}\text { \% giảm trọng } \\
\text { lượng u hạt }\end{array}$ & $\mathbf{P}$ \\
\hline $\begin{array}{l}\text { Lô 1: Dung môi (NaCMC } \\
5 \%)(1)\end{array}$ & $0,1 \mathrm{ml}$ & $512,19 \pm 45,41$ & - & \\
\hline Lô 2: Prednisolon (2) & $5 \mathrm{mg}$ & $292,15 \pm 22,80$ & 42,9 & $\mathrm{p}_{1-2}<0,05$ \\
\hline $\begin{array}{l}\text { Lô 3: Viên nang hố trợ điều } \\
\text { trị eczema (3) }\end{array}$ & $0,6 \mathrm{~g}$ & $313,52 \pm 28,83$ & 38,8 & $\begin{array}{l}\mathrm{p}_{1-3}<0,05 \\
\mathrm{p}_{2-3}>0,05\end{array}$ \\
\hline $\begin{array}{l}\text { Lô 4: Viền nang hồ trợ điều } \\
\text { trị eczema (4) }\end{array}$ & $1,8 \mathrm{~g}$ & $316,72 \pm 24,48$ & 38,2 & $\begin{array}{l}\mathrm{p}_{1-4}<0,05 \\
\mathrm{p}_{2-4}>0,05\end{array}$ \\
\hline
\end{tabular}

Nhận xét: Viên nang hố trợ điều trị eczema ở cả hai mức liều thử: liều tương đương lâm sàng $(0,6 \mathrm{~g} / \mathrm{kg} T \mathrm{~T})$ và liều gấp 3 lần liều tương đương lâm sàng $(1,8 \mathrm{~g} / \mathrm{kg} T \mathrm{~T})$ đều có tác dụng làm giảm trọng lượng khối u tươi có ý nghĩa thống kê khi so sánh với lô chứng $(p<0,05)$. Tác dụng này tương đương với prednisolon liêu $5 \mathrm{mg} / \mathrm{kg}(\mathrm{p}>0,05)$.

Bảng 3.4. Trọng lượng khôi u hạt thực nghiệm khô ở các lô chuột thử nghiệm

\begin{tabular}{|c|c|c|c|c|}
\hline Lô thử (n=10) & $\begin{array}{c}\text { Liều thử } \\
\text { (/ KgTT) }\end{array}$ & $\begin{array}{c}\text { Troọng lượng } \\
\text { (mg, } \mathbf{\pm} \text { SD) }\end{array}$ & $\begin{array}{c}\text { \% giảm trơng } \\
\text { lượng u hạt }\end{array}$ & $\mathbf{P}$ \\
\hline Lô 1: Nước cất (1) & $0,1 \mathrm{ml}$ & $72,40 \pm 8,65$ & - & \\
\hline Lô 2: Prednisolon (2) & $5 \mathrm{mg}$ & $36,15 \pm 4,08$ & 50,1 & $\mathrm{p}_{1-2}<0,05$ \\
\hline $\begin{array}{c}\text { Lô 3: Viên nang hô trợ điều } \\
\text { trị eczema (3) }\end{array}$ & $0,6 \mathrm{~g}$ & $38,02 \pm 4,20$ & 47,5 & $\begin{array}{c}\mathrm{p}_{1-3}<0,05 \\
\mathrm{p}_{2-3}>0,05\end{array}$ \\
\hline $\begin{array}{c}\text { Lô 4: Viên nang hồ trợ điều } \\
\text { trị eczema (4) }\end{array}$ & $1,8 \mathrm{~g}$ & $39,55 \pm 4,39$ & 45,4 & $\begin{array}{c}\mathrm{p}_{1-4}<0,05 \\
\mathrm{p}_{2-4}>0,05\end{array}$ \\
\hline
\end{tabular}

Nhận xét: Viên nang hỗ trợ điều trị eczema ở cả hai mức liều thử: liều tương đương lâm sàng $(0,6 \mathrm{~g} / \mathrm{kgTT})$ và liều gấp 3 lần liêuu tương đương lâm sàng $(1,8 \mathrm{~g} / \mathrm{kgTT})$ đều có tác dụng làm giảm trọng lượng khối u sau khi sấy khô có ý nghĩa thống kê khi so sánh với lô chứng ( $\mathrm{p}$ < $0,05)$. Tác dụng này tương đương với prednisolon liêu $5 \mathrm{mg} / \mathrm{kg}(p>0,05)$.

3.2. Bàn luận. Viên nang hố trợ điều trị eczema được bào chế từ cốm thuốc gồm cao chiết ethanol của bài thuốc hỗ trợ điều trị eczema và tá dược. Trong bài thuốc hỗ trợ điều trị eczema gồm có 6 vị thuốc: kim ngân đằng (Caulis cum folium Lonicerae), hòe hoa (Flos Styphnolobii japonici imaturi), đơn lá đỏ (Folium Excoecariae), núc nác (Cortex Oroxyli), thương nhĩ tử (Fructus Xanthii strumarii), hoàng bá (Cortex Phellodendri), trong đó, mỗi một vi thuốc đều đã thể hiện tác dụng chống viêm trên thực nghiệm như: dịch chiết kim ngân đằng có tác dụng chống viêm, chống phù nề trên chuột gây viêm tai bằng xylen [7], núc nác có tác dụng ức chế giai đoạn cấp của phản ứng viêm trên chuột nhắt trắng [6], hòe hoa và flavonoid của vị thuổc có tác dụng chống viêm trên mô hình in vitro và in vivo [5], dịch chiết ethanol thương nhĩ tử có tác dụng chống viêm trên chuột [4], dịch chiết đơn lá đỏ và flavonoid của vị thuốc dùng theo đường uống có tác dụng chống viêm cấp trên mô hình gây phù bàn chân chuột bằng carageenin [3], dịch chiết ethanol của hoàng bá có tác dụng chống viêm trên mô hình gây viêm tai ở chuột bằng 12-0-tetradecanoylphorbolacetate [8].

ớ trong nghiên cứu, viên nang hỗ trợ điều trị eczema có thành phần từ cao chiết của cả 6 vị thuốc, thể hiện cả tác dụng chống viêm cấp và chống viêm mạn với 2 liều thử: liều thấp $0,6 \mathrm{~g} / \mathrm{kg} T$ và liều cao gấp 3 lần $1,8 \mathrm{~g} / \mathrm{kgTT}$. Kết quả nghiên cứu này là khá tương đồng với các kết quả nghiên cứu đã công bố trước đây của nhóm nghiên cứu [1], [2]. Tuy nhiên, trong nghiên cứu này, chúng tôi đã đánh giá tác dụng chống viêm cấp và chống viêm mạn của viên nang hỗ trợ điều trị eczema được bào chế từ cao chiết ethanol của bài thuốc hố trợ điều trị eczema, mặt khác, chúng tôi đã tiến hành đánh giá trên động vật chuột cống trắng, trong khi, các nghiên cứu đã công bố trước đây sử dụng dạng cao chiết bán thành phẩm của bài thuốc hố trợ điều trị eczema và sử dụng động vật chuột nhắt trắng. Như vậy, trong nghiên cứu này, chúng tôi đã đánh giá tác dụng chống viêm đối với viên nang hố trợ điều trị eczema là dạng bào chế cuối cùng đến tay người dùng thuốc. Kết quả nghiên cứu cho thấy, viên nang hỗ trợ điều trị eczema thể hiện tác dụng chống viêm trên thực nghiệm, dùng hố trợ điều trị eczema.

\section{KẾT LUÂ̂N}

- Viên nang hỗ trợ điều trị eczema ở liều tương đương lâm sàng $0,6 \mathrm{~g} / \mathrm{kg} T$ và liêu gấp 3 
lần liều tương đương lâm sàng $(1,8 \mathrm{~g} / \mathrm{kgTT})$ có tác dụng chống viêm mạn ở chuột cống trắng trên mô hình gây viêm phúc mạc. Khác biệt giữa 2 mức liều thử không có ý nghĩa thống kê.

- Viên nang hỗ trợ điều trị eczema ở liều tương đương lâm sàng $(0,6 \mathrm{~g} / \mathrm{kg} T)$ và liêu gấp 3 lần liều tương đương lâm sàng $(1,8 \mathrm{~g} / \mathrm{kg} T \mathrm{~T})$ đều có tác dụng chống viêm mạn trên mô hình gây u hạt thực nghiệm. Tác dụng này tương đương với prednisolon liều $5 \mathrm{mg} / \mathrm{kg}(p>0,05)$.

Lời cảm ơn: Nghiên cứu này được thực hiện trong khuôn khổ đề tài nghiên cứu khoa học công nghê cấp Thành phố Hà Nội, mã số 01C06/0-2017-3. Xin chân thành cảm ơn hỗ sự hỗ trợ kinh phí và tạo điều kiện để nghiên cứu này được thực hiện thuận lợi của UBND Thành phố Hà Nội và Sở Khoa học Công nghệ Hà Nội.

\section{TÀI LIÊU THAM KHẢO}

1. Nguyễn Manh Tuyển và cs (2015), "Đánh giá tác dụng chống viêm thực nghiệm của cao đặc bào chế từ dịch chiết ethanol bài thuốc EZ", Tạp chí Dược học, 471, tr. 6 - 10.

2. Nguyến Mạh Tuyển và cs (2015), "Đánh giá tác dung chống viêm thực nghiệm của cao đặc bào chế từ dịch chiết nước bài thuốc EZ", Tạp chí dược học, 474, tr. 50-54.
3. Chan BC., Hon KL., Leung PC., Sam SW., Fung KP., Lee MY., Lau HY. (2008), "Traditional Chinese medicine for atopic eczema: PentaHerbs formula suppresses inflammatory mediators release from mast cells", Ethnopharmacol journal, 120 (1), pp. 85-91.

4. Han T., Li HL., Zhang OY., (2007, "Bioactivityguided fractionation for anti-inflammator and analgesic properties and constituents of Xanthium strumarium L.", Phytomedicine Journal, 14 (12), pp. 825-829.

5. He X., Yajun B., Zefeng $Z$, (2016), "Local and traditional uses, phytochemistry, and pharmacology of Sophora japonica L.", Ethnopharmacol Journal, pp. 160-182.

6. Lalrinzuali K., Vabeiryureilai M., Jagetia G.C. (2016), "Investigation of the Anti-Inflammatory and Analgesic Activities of Ethanol Extract of Stem Bark of Sonapatha Oroxylum indicum In Vivo", International journal of inflammation.

7. Lu H. (2015), "Study on the isolation of active constituents in Lonicera japonica and the mechanism of their anti-upper respiratory tract infection action in children", African health sciences, 15 (4), pp. 1295-1301.

8. Peng W., Ming Q., Han P., (2014), "Antiallergic rhinitis effect of caffeoxyl xanthiazonosid isolated from fruits of Xanthiumstrumarium $L$. in rodent animals", Phytomedicine journal, 21 (6), pp. 824-829.

\section{HÌNH DẠNG KHUÔN MẶT CỦA MộT NHÓM TRẺ 12 TUỔI NGƯờI VIỆT TÁI HÀ NộI TRÊN ẢNH CHUẨN HÓA THẲNG}

\section{TÓM TẮT}

Hình dang khuôn mặt luôn được coi trọng trong điều trị thẩm mỹ. Tuy nhiên những nghiên cứu về các chỉ số trên khuôn mặt và sự tương quan các tỷ lệ khuôn mặt chưa thực sự được tìm hiểu nhiêu ở Việt Nam, đăc biêt ở trẻ lứa tuổi 12. Muc tiêu: Mô tả hình dạng khuôn mặt trên ảnh chuẩn hóa của một nhóm trẻ 12 tuổi người Viêt bằng phương pháp đo trên ảnh chuẩn hóa năm 2016 - 2017 tại Hà Nội. Đối tượng và phương pháp nghiên cứu: Nghiên cứu mổ tả cắt ngang trên 905 nam và 908 nữtại một số trường trung hoc cơ sở trên đia bàn thành phố Hà Nôi. Kết quả: Ở ba hình dạng khuôn mặt, nhìn chung các kích thước ngang có sứ thay đổi, khác biêt hầu hết có ý nghĩa thống, nhìn chung các góc mặt nghiêng không có sự khác biệt về kiểu măt, một số ít khác biệt chî thể hiện ở một giới, hầu hết các chỉ số theo chiều dọc

*Viện đào tạo Răng Hàm Mặt- Trường Đại học Y Hà Nộ Chịu trách nhiệm chính: Võ Trương Như Ngọc Email: votruongnhungoc@gmail.com Ngày nhận bài: 3.3.2021

Ngày phản biên khoa học: 23.4.2021

Ngày duyệt bài: 6.5.2021
Võ Trương Như Ngọc*, Vũ Lê Hà*

khác biệt đều có ý nghĩa thống kê cao thể hiên trên ba dạng khuôn mặt và thể hiện cả sự khác biệt giữa hai giới. Kết luận: Dang khuốn mặt phổ biến là dang Oval $(48,98 \%)$, tiếp đển là dạng vuông $(29,18 \%)$, thấp nhất là mặt tam giác $(21,84 \%)$. Hinh dang măt tương ứng với các tỷ lệ ngang khuôn mặt: Mặt hình vuông có tỳ lê Ft-Ft = Ży-Zy, mặt hình oval với Zy-Zy $>$ Ft-Ft và Zy-Zy > Go-Go, và mặt hình tam giác với Ft-Ft $>$ Zy-Zy > Go-Go.

Từ khóa: Nhân trắc học, ảnh chuẩn hóa,tỉ lệ khuôn mặt.

\section{SUMMARY \\ FACIAL SHAPES OF 12-YEAR-OLD STUDENTS IN HANOI: FRONTAL PHOTOGRAMMETRIC STUDY}

Facial analysis is always importantin esthetic treatment. However, researchs about face shapes and porpotions in Vietnam is not quite much, especially in children at 12 year of ages. Purpose of research: To determine some of facial shapes and ratio indices for 12-year-old Vietnamese in Hanoi year of 2016 2017. Method of research: Cross sectional study in over 905 males and 908 females at some secondary schools in Hanoi city. Results: In the three face 